\title{
Riparian Areas of Greece: Their Definition and Characteristics
}

\author{
G. N. Zaimes, V. Iakovoglou, D. Emmanouloudis" and D. Gounaridis
}

Department of Forestry and Natural Environment Management, TEI of Kavala, Drama 66100, Hellas.

Received 1 June 2010; Revised 6 July 2010; Accepted 3 August 2010

\begin{abstract}
Riparian areas are unique and of high importance ecosystems because they are adjacent to surface freshwater bodies such as streams, rivers and lakes. They are the semi-aquatic transitional zones (ecotones) between terrestrial and aquatic ecosystems. Water, soil and vegetation are the three main characteristics that differentiate them compared to other ecosystems. Furthermore, they are present in all biomes (from deserts to tropical forests) and are found in a great range of hydrologic and geomorphologic conditions that results in a great variety of riparian habitat types. In Greece, there are five major riparian forest habitat types that also occur in most of the semi-arid Mediterranean regions. Frequent disturbance is another unique characteristic that differentiates riparian areas. The major disturbances that shape riparian areas in Greece are unpredicted flood and drought events, as well as fires but to a lesser degree. Wetlands are another important semi-aquatic ecosystems that many consider as synonymous to riparian areas. In reality, these two ecosystems overlap but they are also different since wetlands are considered as "wetter" and less disturbance driven than riparian areas.
\end{abstract}

Keywords: ecosystem, ecotone, Greece, riparian areas, semi-aquatic, semi-arid, wetland.

\section{Introduction}

Riparian is a term that is frequently used in most natural resource sciences today. It describes a key ecosystem that provides many useful services to humans such as improved water quality, fish and wildlife habitat [1]. However even today, many land managers and especially the general public do not have a clear picture and definition of what a riparian area is.

The term "riparian areas" that describes areas adjacent to surface freshwater bodies, first appeared in the scientific literature in the early 1970's [2]. Since then, it has been officially accepted by the scientific community with hundreds of articles and dozens of books being published, that discussed issues related to riparian areas. It originates from the Latin word "riparius" that means river bank. The Greek equivalents of the term riparian are

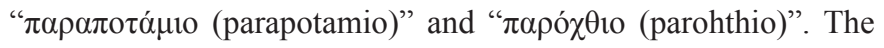

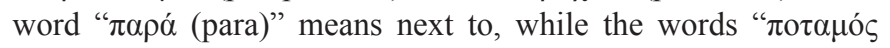
(potamos)" and "ó $\chi \theta \eta$ (ohthi)" mean river and bank, respectively. This translates to areas next to a river or a bank of a river. Other English terms that are used worldwide to describe these areas are "riparian woodlands", "riparian forests", "riparian buffer zones", "riparian strips", "riparian zones", "cottonwood floodplains", "alluvial floodplains", "floodplain forests", "bosque woodlands", "cienegas" and "meadows."

While the term riparian is relatively new, speaking in scientific terms, the relationship between humans and riparian areas is quite old [2]. Some of the early greatest civilizations were developed around riparian areas. The Egyptian Empire thrived along the banks of the Nile River, while the Persian Empire along the banks of the Tigris and Euphrates Rivers. Even today most of the world's greatest cities are along the banks of rivers [3].

The relatively young acceptance of the use of the term riparian area [2] and the many different disciplines that study them (plant ecology, hydrology, fisheries, wildlife, geology, geomorphology, forestry, soil science, range science, biology, entomology, and even engineering) have led to many different and often contradicting definitions [4]. The National Research Council in 2002 [5] defines them as "Riparian areas - Transitional between terrestrial and aquatic ecosystems (Figure 1) and are distinguished by gradients in biophysical conditions, ecological processes, and biota. They are areas through which surface and subsurface hydrology connects waterbodies with their adjacent uplands. They include those portions of terrestrial ecosystems that significantly influence exchanges of energy and matter with aquatic ecosystems (i.e., a zone of influence). Riparian areas are adjacent to perennial, intermittent, and ephemeral streams, lakes, and estuarine-marine shorelines". This is the definition adopted by the authors.

To truly define any ecosystem it is essential to understand its main characteristics that differentiate it and make it unique. It is also important to understand that although all riparian areas do 
have the same main characteristics, they also have unique characteristics depending on the biome they are located in and their hydrologic and geomorphologic conditions. In this literature review, the riparian areas of Greece are defined as well as their main characteristics are described while comparing them to their adjacent terrestrial and aquatic ecosystems.

\section{Characteristics of Riparian Areas}

\subsection{General Characteristics}

Riparian communities are not biomes. Biomes are major ecological community types that are determined primarily by their climate (a very broad scale factor) [6]. Examples of biomes are rainforests, savannas, chaparral, grasslands and deserts. However, all biomes have riparian areas adjacent to their surface freshwater bodies. Consequently, riparian areas can be found in a wide range of climatic, hydrologic geomorphic and ecological environments. In Greece, riparian areas can be found from high elevation mountainous conifer forests through intermediate-elevation broadleaf woodlands, to low-elevation shrublands "maquis" with dense thickets of evergreen shrubs and small trees and finally to shrublands "phrygana" that are common at the coastal areas $[7,8]$.

Riparian areas are ecosystems. Ecosystems include organisms, such as the plants and animals (biotic part) and their immediate environment (abiotic part). Their organisms interact with their immediate environment and are more influenced by local scale factors [9]. Each ecosystem is unique and differs significantly from other ecosystems.

Similarly, riparian areas are distinctive and unique compared to the adjacent ecosystems mainly due to three main characteristics: i) water, ii) soil and iii) vegetation. The combination of the water-soil-vegetation characteristics of these areas reflects the influence of the higher available moisture quantities compared to their adjacent terrestrial upland ecosystem [10]. In addition, riparian ecosystems are substantially dryer than the adjacent aquatic ecosystems that are inundated by water either year-round or for long periods of time. Consequently, riparian areas are transition zones or ecotones with characteristics of both aquatic and upland terrestrial ecosystems (Figure 1).

Water is the most important characteristic because it is essential for the survival of the riparian areas, while also being the driving force that shapes them. Every ecosystem and its living organisms cannot survive without water. Water is even more essential in semi-arid and arid regions. In these environments it is the most limiting element that leads to higher competition among the living organisms when compared to more humid regions. Naiman et al. [1] state that the water and the solutes and sediments that it carries, creates, structures, maintains and destroys the riparian ecosystem. The proximity of riparian areas to surface freshwater bodies is also directly correlated to the other two main characteristics of riparian areas, soil and vegetation. To fully understand the influence of water, it needs to be discussed in the context of the other two factors.

Riparian soils have greater water availability (higher moisture), compared to the surrounding terrestrial landscape because they are so close to a surface freshwater body that can lead to hydric characteristics. In addition, because of their close proximity

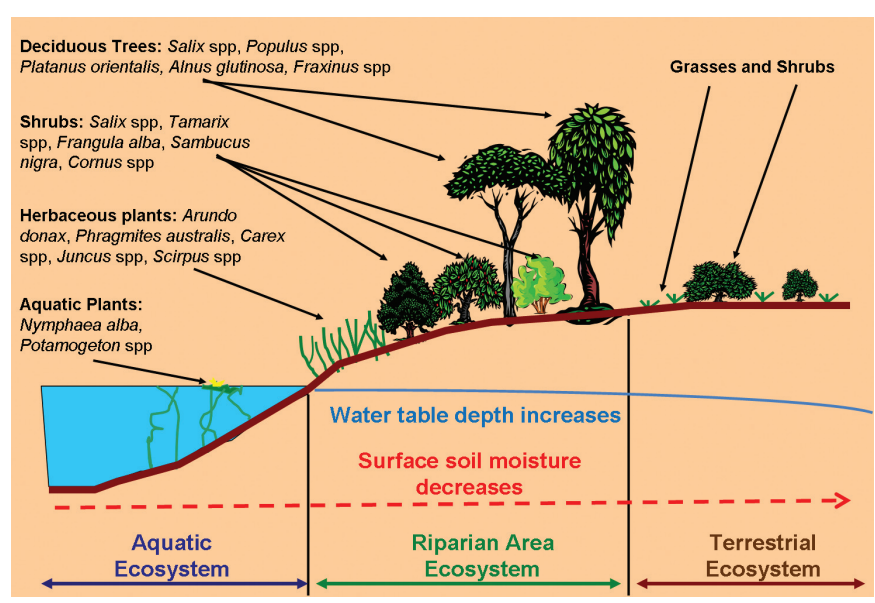

Figure 1. The location of riparian areas (Illustration by G. Zaimes; modified from [11]) and common riparian plants species of Greece [12].

to a surface freshwater body, processes such as water erosion and deposition, also frequently disturb these soils. As a result, riparian soils have higher spatial diversity that can be composed by depositional and/or erosional soils that are considered young and poorly developed (without well-developed soil horizons) compared to the surrounding upland terrestrial soils.

Riparian vegetation is a very distinctive characteristic in comparison to the surrounding landscape, particularly in semi-arid and arid regions (Figure 2). In general, riparian vegetation is denser, taller and in many cases with different species and more diverse composition than the adjacent upland terrestrial ecosystems. This is because of the greater water availability (higher soil moisture) and their unique soils that are frequently disturbed. Riparian vegetation, in most cases, have year around access to water because of the high water table $[13,14]$. In contrast, the vegetation of upland terrestrial ecosystems have access to water only during the precipitation events and possibly some days afterwards. The greater and longer periods of water availability of the riparian areas reflects their ability to support more plants that grow faster and to larger dimensions. These unique soil conditions, also lead to different plant species that occupy these areas. Most of the tree species are pioneers that thrive in open sites right after a disturbance event. Johnson et al. [15] classified the plant species based on their occurrence frequency in riparian areas into the following categories: i) obligate riparian (91-100\% occurrence), ii) preferential riparian (76-90\%), iii) facultative riparian (26-75\%) and iv) nonriparian $(0-25 \%)$. Common obligate and preferential riparian species in Greece are trees such as Salix spp., Populus spp., Platanus orientalis, Alnus glutinosa, Fraxinus spp., shrubs such as Salix spp., Tamarix spp., Frangula alba, Sambucus nigra, Cornus spp. and herbaceous plants such as Arundo donax, Phragmites australis, Carex spp., Juncus spp., Scirpus spp. [12] (Figure 1).

\subsection{Climatic and Hydrologic regimes}

The climate of Greece is Mediterranean, but because of its high topographic relief it ranges from dry Mediterranean in the southeastern parts of Greece and the Aegean islands, to humid in the northern and western parts of Greece, to alpine in the tall mountain 
regions such as Pindus and Rhodope. These climatic regimes also exhibit great precipitation variability from less than $600 \mathrm{~mm}$ in the Dry Mediterranean region to more than $1000 \mathrm{~mm}$ in the Alpine regions. This variation impacts the hydrologic processes, water availability and vegetative cover of their respective riparian areas.

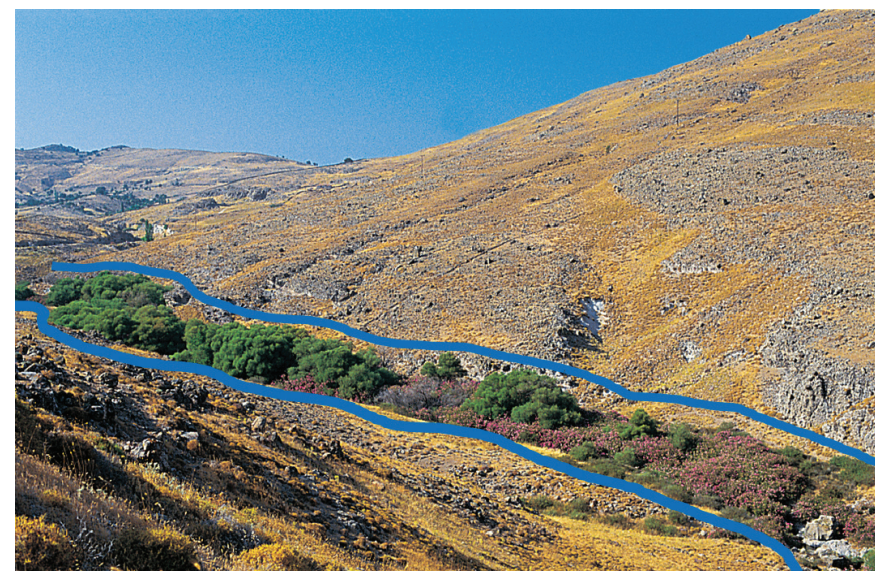

Figure 2. Riparian areas (between the blue lines) have much more lush vegetation and different plant species than upland terrestrial areas (photo by K. Vidakis).

In the northern and the western regions of Greece that are primarily humid, most precipitation infiltrates the soil and reaches the stream as subsurface flow and groundwater (Figure 3). Groundwater contributes to stream flow almost year round and most streams and rivers have perennial flow. This also results in high riparian soil moisture levels. In contrast, in southeastern Greece and the Aegean islands that have a dry Mediterranean climate, most precipitation becomes overland flow and reaches the stream in a relatively short period of time after the precipitation event (Figure 3). This leads to primarily intermittent or ephemeral streams and rivers. These types of streams and rivers remain without surface flow present for considerable periods of time. When stream flow is present in their channels, it typically contributes water to the groundwater. Finally,

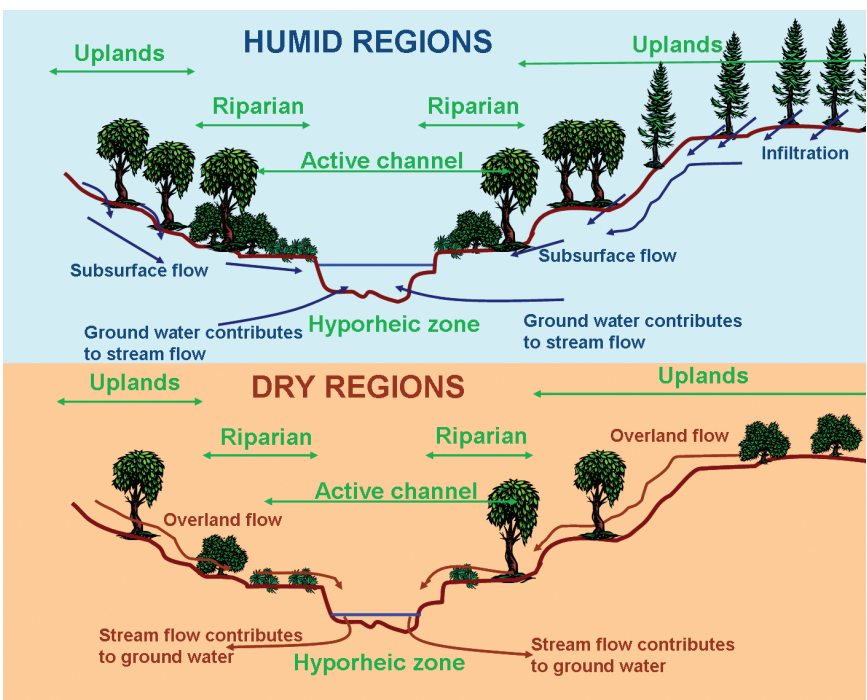

Figure 3. Precipitation follows different hydrologic pathways to reach the stream in humid and dry regions and impacts riparian vegetation density and composition (illustration by G. Zaimes; modified from [15]). The hyporheic zone is defined as the area of the stream bed that exchanges water between the stream flow and the groundwater. the streams and rivers of the alpine regions are similar to the humid regions with the addition of spring snowmelt runoff that also substantially contributes to stream flow [1].

The increased precipitation, stream flow and soil water moisture of the humid regions enables its riparian areas to sustain more lush vegetation than the dry regions. The effects of the higher precipitation amounts of these regions are evident in their terrestrial upland ecosystems that also maintain lush vegetation. This makes it difficult to clearly define the boundaries between the humid riparian and adjacent terrestrial ecosystems. In contrast, the transition zone between riparian and upland terrestrial ecosystems is more easily identifiable in the dry regions. Their transition line is abrupt because the surrounding terrestrial habitat is much drier with shorter and less dense vegetation than the adjacent riparian areas (Figure 2).

\subsection{Surface Water Body Hydrologic Characteristics}

The type of the water body and its flow characteristics impact the natural processes of the riparian areas. Riparian areas are natural when they are adjacent to the streams, rivers and lakes, or man-made when they are adjacent to canals, ponds and reservoirs. When riparian areas are along the banks of stationary water (lakes and ponds) they are called lentic systems [17]. In contrast, if the water is moving (streams and rivers) these riparian areas are called lotic systems [18]. Additionally, the lotic systems can differ based on their size and their flooding frequency. Streams and their adjacent areas are sensitive even to individual precipitation events that lead to many high stream flows and floods year around [19]. In contrast, large perennial rivers have much larger watersheds with areas that can be larger than the scale of the precipitation event. Consequently, rivers are less sensitive to individual precipitation events with floods and high stream flows occurring primarily during the rainy season [19].

Johnson et al. [15] characterized riparian areas based on the flow conditions of the stream or river (Figure 4). Specifically, they examined the presence of flowing water in the channel and the connectivity of the stream flow to the groundwater. Hydroriparian areas are associated primarily with perennial streams or rivers. The soils are hydric or have substrates that are never dry or are dry for short periods. Their vegetation consists primarily of obligate and preferential riparian plants. Mesoriparian areas are associated with intermittent streams or rivers. The soils are non-hydric and have substrates that are seasonally dry. Vegetation consists of a mixture of primarily preferential and facultative riparian, but also obligate riparian and non-riparian plants. Xeroriparian areas are typically associated with ephemeral streams or rivers. Soils are non-hydric and dry most of the year. Their average annual soil moisture is higher than the surrounding uplands, but only during or shortly after rainfall events. These events enhance the storage and accumulation of water in the stream channel and its banks. This higher available soil moisture at the xeroriparian areas leads to a much denser vegetation than the adjacent terrestrial uplands. Plant species that are present are typically facultative riparian and nonriparian plants, while in some cases there are preferential riparian plants. In contrast, at the hydroriparian and mesoriparian areas the groundwater provides consistent moisture to the vegetation year around, in addition to any circumstantial surface moisture during local rainfall events that leads to a greater presence of obligate and preferential riparian plants. 


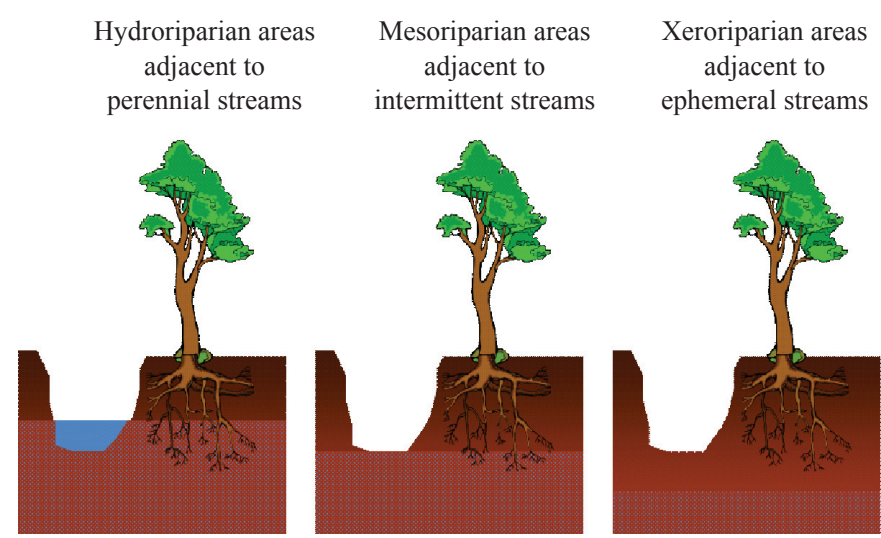

Figure 4. Hydroriparian, mesoriparian and xeroriparian areas are adjacent to perennial, intermittent and ephemeral streams/rivers, respectively (illustration by G. Zaimes; modified from [3]). Groundwater is represented with the light brown color in the soils.

\subsection{Geomorphologic and Soil Characteristics}

Riparian areas can also differ depending on the geomorphologic settings of the sites [10] that affect the soil's erosional and depositional patterns as well as the type of the vegetation that is present (Figure 5). Streams or rivers can flow though narrow V-shaped settings or broad valleys. Through V-shaped settings, their flow is constrained and it has higher stream velocities and erosion because of the steeper slopes compared to their counterparts in the broad valleys. Typically, most constrained streams or rivers are in the mountain regions while once they reach the lowland areas, they become unconstrained (flowing in broad valleys). The unconstrained streams and rivers have smaller slopes and stream velocities that lead to the development of meanders, deposition of the eroded material and the development of extensive floodplains. In these broad valleys the cut and fill process dominate. On the outside bends of meanders water flows faster and this is the erosional surface, called the cut bank. In contrast, in the inside bends stream flow is much slower with deposition (the fill process) being the dominant process that leads to the presence of point bars. Finally, in these unconstrained streams and rivers the interactions between water and sediment movement and the floodplains develop a number of lotic riparian geomorphic features such as oxbows, natural levees and crevasse splays [1] that impact the vegetation types that cover them.

The geomorphic setting also influences the size of the parent material and the depositional mode. Low-gradient broad valley settings are usually fine-textured with small areas of coarse-textured deposits [20, 21]. In contrast, parent materials of high-gradient narrow V-shaped settings, or alluvial fans/terraces that occur at mountains tend to be coarse-textured, that reflects higher stream power [20, 21].

In broad valley floodplains, stream flows can frequently exceed bankfull discharge capacity with its water flowing onto the floodplain. The bankfull discharge is the quantity of water (discharge) that controls the form of the channel and the distribution of materials in it. The increased cross-sectional area along with the hydrologic roughness of the floodplain decreases substantially the stream velocities and the sediment settles as a layer on the surface (vertical accretion). The general characteristics of the vertically accreted soils are [20,22]: i) distinct horizon boundaries with often sharply contrasting textures that are indicative of the different flooding events,

ii) organic matter that decreases irregularly with depth and

iii) presence of buried horizons.

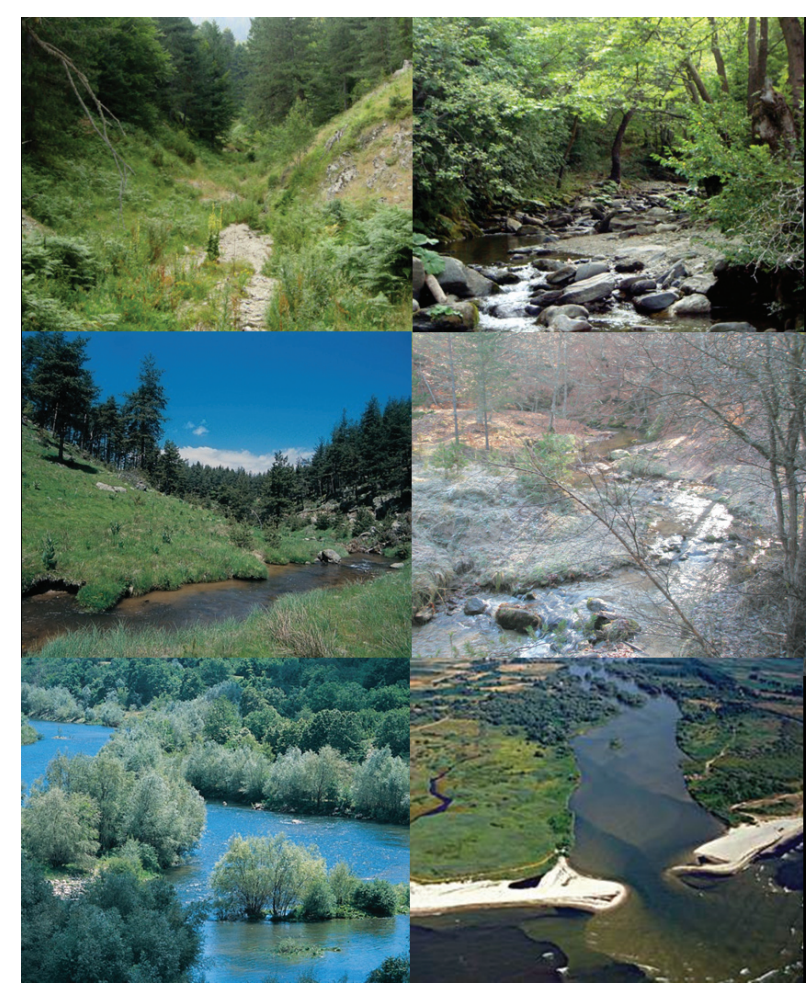

Figure 5. Different vegetation types of riparian areas along different geomorphic and hydrologic setting for the headwater to the delta of the river (photos by K. Vidakis, G. Zaimes and V. Iakovoglou).

In general, sediment size decreases as the distance from the channel's edge increases [5]. However, the influence of the floodplain surface irregularities and the vegetation also affects the flow velocity, the size and the amount of vertically accreted sediments causing heterogeneous depositional patterns across the floodplain $[20,23,24]$. As a stream channel meanders it crosses its floodplain and undercuts and erodes the outside channel banks. The newly derived parent materials are transported and deposited downstream on the point bars as lateral accretion [22]. These sediments are deposited in a more turbulent environment than the vertically accreted sediments. As a result, laterally accreted soils have:

i) thick horizons containing rock fragments,

ii) organic matter content that is homogenous or decreases regularly with depth and iii) no buried horizons [20, 22].

Overall, the aerial extent of laterally accreted soils is more limited than vertically accreted soils. Laterally accreted soils are also rarely found in V-shaped canyons, due to the limited lateral movement of the stream in these geomorphic settings. Through time, the thalweg (the deepest part of the channel) of the stream channel may shift its position. This can lead to sites that lateral accretion was dominant but now vertical accretion dominates. This results in soil profiles with evidence of both vertical and lateral accretion.

In situ processes can also dominate soil formation of riparian areas. When the channel thalweg continues to shift its position away and/or lateral accretion increases the elevation of the site above the flood prone elevation, these soils begin to have char- 
acteristics of upland soils over time because of the lack of disturbances in these areas. The in situ processes tend to erase the evidence of both lateral and vertical deposition. Soils influenced by in situ process can be characterized by:

i) the accumulation of the surface soil and the gradual decrease of organic matter with depth,

ii) the development of soil structure and

iii) the dissolution and redistribution of carbonates, clays and other materials.

The in situ development is common at the riparian soils of terraces.

\subsection{Habitat characteristics}

The high variability in riparian areas (Figure 5) due to the climatic, hydrologic and geomorphologic characteristics impacts the vegetation type. The vegetation of riparian areas can differ from areas that are dominated primarily by woody vegetation to areas that are dominated primarily by herbaceous vegetation (Figure 5). Even the woody and herbaceous species that occur at the riparian areas can vary widely. The Natura 2000 program has differentiated five major forest habitat types for Greece [12]:

i) Alluvial forests with Alnus glutinosa and Fraxinus excelsior (Alno-Pandion, Alnion incanae, Salicion albae). Habitat Natura 2000 code: $91 \mathrm{E} 0$.

This habitat type includes: a) mixed riparian forests of Fraxinus excelsior and Alnus glutinosa of the temperate and Boreal Europe and b) mixed riparian woods of Alnus incana and Alnus glutinosa with galleries of Salix alba. In both cases, the soils are rich in alluvial deposits, periodically inundated during flooding but otherwise well-drained and aerated during low-water table conditions. The herbaceous layer is well developed that includes large herbaceous species (non-grasses) and various spring vernal geophytes. These riparian forests are present at the mountainous and semi-mountainous areas of Greece. Detailed information regarding the species composition of this habitat type is provided by Table 1 .

ii) Riparian mixed forests of Quercus robur, Ulmus laevis and Ulmus minor, Fraxinus excelsior or Fraxinus angustifolia, along major rivers (Ulmenion minoris). Habitat Natura 2000 code: 91F0.

These hardwood forests with a well developed understory are established on recent alluvial deposits of the floodplain of major rivers. The alluvial soils are inundated by water during regular flooding or following the raising of the water table. The soils may be well drained or remain wet between inundations. This riparian habitat type is commonly found on flat areas in elevations between $0-200 \mathrm{~m}$. Detailed information regarding the species composition of this habitat type is provided by Table 1 .

iii) Salix alba and Populus alba galleries. Habitat Natura 2000 code: 92A0.

These riparian forests are the habitat type that is most common in the Mediterranean and Central Eurasian region. Typically they are characterized by multi-layered canopies dominated by Populus spp. and/or Salix spp. Elevation wise this habitat type can be found between $0-1200 \mathrm{~m}$ but is more common between $0-600 \mathrm{~m}$. The relief is either flat or with gentle slopes $(0-10 \%)$. Detailed information regarding the plant species composition of this habitat type is provided by Table 1 .

iv) Platanus orientalis and Liquidambar orientalis woods (Plantanion orientalis). Habitat Natura 2000 code: 92C0.

This habitat type includes forests and woods, with most of the riparian areas being dominated by Platanus orientalis and in some cases Liquidambar orientalis such as in the island of Rhodes, Greece. It is abundant primarily in the Balkan Peninsula in a wide range of environments. Topographically these environments range from flat to gently sloping at low elevations to steep slope areas at higher elevations, with a maximum elevation of $1300 \mathrm{~m}$. They are adjacent to rivers with perennial flow or small mountainous torrents. The most important factor for their existence is the presence of a high water table. Detailed information regarding the species composition at this habitat type is provided by Table 1 .

v) Southern riparian galleries and thickets (Nerio-Tamaricetea and Securinegion tinctoriae). Habitat Natura 2000 code: 92D0.

Tree galleries and thickets of similar low woody formations of perennial or ephemeral streams and wetlands of the thermoMediterranean zone, are included in this habitat type. These galleries and thickets are primarily present at the southern and the eastern part of the country and the islands of the Aegean, Ionian and Cretan Sea. They occupy areas of all aspects that are flat or with gentle slopes. Elevation wise, this habitat type is present in areas below sea level and up to $850 \mathrm{~m}$. Detailed information regarding the species composition at this habitat type is provided by Table 1 .

\subsection{Temporal characteristics - Floods and Droughts}

Ecosystems change through time because they are not static. Disturbance-driven ecosystems have drastic changes that can occur within a short period of time. Riparian areas are disturbance-driven [25] with rapid changes in their soil and vegetation composition and condition depending on the weather conditions and the extent and frequency of the disturbances of a particular year [26].

In semi-arid regions like the Mediterranean, floods and droughts are the main abiotic disturbance drivers of riparian areas. Precipitation levels highly vary in space and time. This leads to long periods of droughts, punctuated by extreme flooding events. In these environments the intervening periods of stream base flow (drought periods) occur more irregularly and last longer compared to humid regions. Continual drought can minimize and even completely diminish the presence of surface stream flow.

Large flood events damage, scour and remove vegetation, while also eroding, transporting and depositing sediments in the riparian areas. These activities lead to bare surfaces that are re-colonized with new fast growing riparian plant species. Most riparian plants are pioneer, shade intolerant species that successfully regenerate and maintain their populations under open canopy conditions. 
Table 1. The major tree, shrub, vine and herbaceous species that are present in the five forest riparian habitat types of Greece based on the Natura 2000 Code [12]

Forest Riparian Habitat Type Natura 2000 of Greece

\begin{tabular}{|c|c|c|c|c|}
\hline $\begin{array}{c}\text { Alno-Pandion, Alnion } \\
\text { incanae, Salicion albae } \\
\text { Code:91E0 }\end{array}$ & $\begin{array}{l}\text { Ulmenion minoris } \\
\text { Code: } 91 \mathrm{~F} 0\end{array}$ & $\begin{array}{l}\text { Salix alba and } \\
\text { Populus alba } \\
\text { Code:92A0 }\end{array}$ & $\begin{array}{l}\text { Plantanion orientalis } \\
\text { Code: } 92 \mathrm{C} 0\end{array}$ & $\begin{array}{l}\text { Nerio-Tamaricetea and } \\
\text { Securinegion tinctoriae } \\
\text { Code:92D0 }\end{array}$ \\
\hline \multicolumn{5}{|c|}{ Trees } \\
\hline Alnus glutinosa & Fraxinus angustifolia & Populus alba & Platanus orientalis & \\
\hline Alnus incana & Populus alba & Populus nigra & Salix alba & \\
\hline Fraxinus angustifolia & $\begin{array}{l}\text { Quercus robur subsp. } \\
\text { pedunculiflora }\end{array}$ & Salix alba & Alnus glutinosa & \\
\hline Fraxinus excelsior & Ulmus laevis & Salix nigra & Ulmus minor & \\
\hline Platanus orientalis & Ulmus minor & Fraxinus angustifolia & $\begin{array}{l}\text { Cercis siliquastrum (north- } \\
\text { ern Greece) }\end{array}$ & \\
\hline \multirow[t]{2}{*}{ Salix alba } & & Ulmus minor & $\begin{array}{l}\text { Liquidambar orientalis } \\
\text { (Rhodes, Greece) }\end{array}$ & \\
\hline & & Acer semprevirens & & \\
\hline \multicolumn{5}{|c|}{ Shrubs } \\
\hline Corylus avellana & & Salix purpurea & Nerium oleander & Nerium oleander \\
\hline Ficus carica & & Salix elaeagnos & Rubus sanctus & Tamarix spp \\
\hline Rubus spp. & & Salix amplexicaulis & Salix spp. & Vitex angus-castus \\
\hline Sambucus nigra & & Salix xanthicola & Vitex angus-castus & Phoenix theophrastii \\
\hline & & & Myrtus communis & \\
\hline
\end{tabular}

Vines

\begin{tabular}{llll}
\hline Clematis vitalba & Calystegia sepium & Clematis vitalba & Hedera helix \\
Hedera helix & Clematis vitalba & Cynachum acutum & Vitis vinifera \\
Periploca graeca & Hedera helix & Hedera helix \\
Smilax excelsea & Humulus lupulus & Humulus lupulus \\
& Periploca graeca & Periploca graeca \\
& Tamus communis & Smilax excelsa \\
& Smilax excelsea & Vitis vinifera \\
& &
\end{tabular}

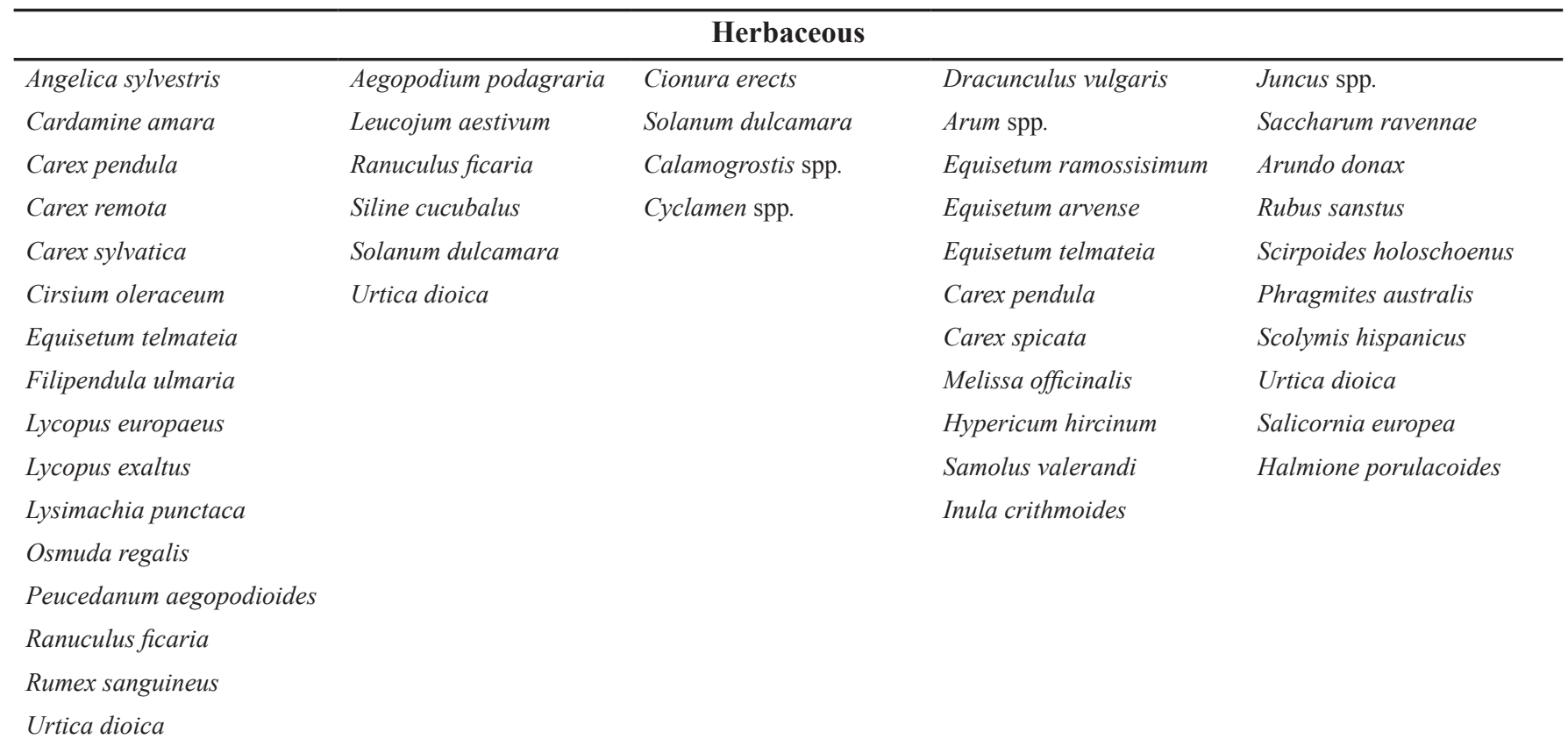


Floods are an essential regenerative mechanism for them [27]. In addition, these species can tolerant water inundated conditions for short periods of time. These frequent disturbances also lead to unique soils in the riparian areas compared to the terrestrial areas. These soils are spatially highly variable and generally undeveloped (young) with hydric characteristics. The deposited sediments are essential for the riparian areas because they replenish nutrients [5] and make these soils highly fertile. Figuratively speaking, these large floods are the "reset button" for the riparian areas. Extreme flood events take riparian areas back to their initial stage; areas with bare soils and without any vegetation.

To better understand how floods and droughts impact riparian systems, it is important to briefly overview a flood and drought cycle. An extreme flood or floods can even remove the woody vegetation leaving the surface soil completely bare. After the flood event, the stream will eventually get back to its normal flow conditions (stream base flow conditions). During this period, the bare soil sites start being re-colonized by the newly established riparian vegetation. If the drought is prolonged, a common characteristic of semi-arid regions, the water-width of the stream channel decreases substantially or it completely disappears (no surface stream flow). Streams may not have flow for a significant part of the year (intermittent and ephemeral streams). As a result, riparian vegetation encroaches into the stream channel and onto the in-stream channel bars. This increases the aerial extent of the riparian vegetation. If drought persists for extensively prolonged periods (many years) and/or is very severe, it can lead to the death of the riparian vegetation. So both severe droughts and the extreme floods can reduce the aerial extent of the riparian vegetation. Drought impacts take several years to affect and change the riparian areas, while flood impacts cause more immediate and drastic changes.

Fires can also be a very important type of disturbance that can affect riparian areas directly or indirectly. The vegetation that occurs in the Mediterranean region has fire-prone species such as Pinus brutia, Pinus halepensis and Quercus coccifera. The material of these species is like "fire fuel" that can induce frequent fires, especially in the dry regions of Greece during the summer season. For many of the species, fire is an important regenerative mechanism. Fires can burn the riparian forests (direct impact) but are more likely to burn the drier upland terrestrial more fire-prone forests (indirect impact). This leaves large bare burned areas in the uplands that are susceptible to excessive water runoff and erosion. Substantial precipitation events in these areas can lead to large peak floods that can destroy the remaining riparian vegetation and deposit large amount of sediment that originate form the uplands. In other words, fires impact the crucial flood-to-drought cycle of the riparian areas.

Frequent temporal vegetative variation of riparian areas, even in short periods, should be expected in semi-arid regions, like Greece. Through time, the riparian vegetation can expand by encroaching the stream channels (droughts) or contract and can even be completely eliminated (floods, severe droughts or fires). Some of these changes are very sudden (floods and fires), while others take some time (droughts). In contrast, the riparian areas of the humid regions of Europe also experience temporal variation but to a much smaller and less variable degree when compared to the riparian areas of the semi-arid regions.

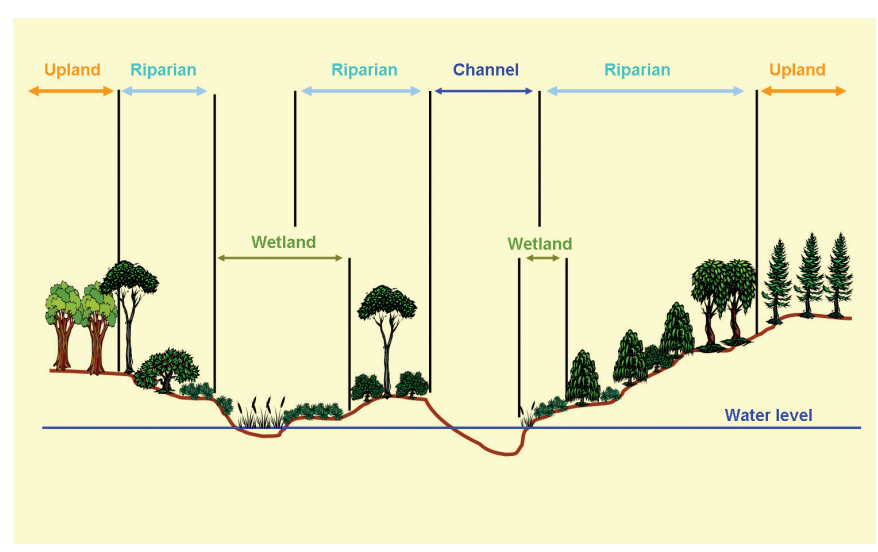

Figure 6. Delineating between riparian and wetlands areas (Illustration by G. Zaimes; modified from [30]). Riparian areas and wetlands are similar but not synonymous.

\subsection{Riparian areas versus Wetlands}

Wetlands and riparian areas have semi-aquatic characteristics and are ecotones (transition zones) between aquatic and terrestrial ecosystems. These similar characteristics have traditionally led to the use of the terms "riparian areas" and "wetlands" interchangeably. In the past, in some cases the riparian areas were considered a type of wetlands [28]. Today with the advancements in riparian ecology, most scientists considered them as different ecosystems [5].

To better understand the differences between riparian areas and wetland lets define wetlands [29]: "A wetland is an ecosystem that depends on constant or recurrent, shallow inundation or saturation at or near the surface of the substrate. The minimum essential characteristics of a wetland are recurrent, sustained inundation or saturation at or near the surface and the presence of physical, chemical and biological features reflective of recurrent, sustained inundation or saturation. Common diagnostic features of wetlands are hydric soils and hydrophilic vegetation. These features will be present except where specific physicochemical, biotic, or anthropogenic factors have removed them or prevented their development."

The definitions for wetlands (above) and riparian areas (in Chapter 2), indicate that riparian areas can be the same, more expansive or more restrictive than wetlands (Figure 6). Riparian areas might be more expansive because they include terrestrial areas that are saturated or inundated with water for short periods of time and are not considered wetlands [5]. In contrast, wetlands can also include areas that are under water year around that are not riparian. The longer water inundation and saturation periods of wetlands lead to soils that are always hydric, while riparian areas can also include areas that have non-hydric soils [5]. Finally, most riparian areas are highly connected with each other (because of the stream corridor), linear in shape and ecosystems high in energy because they are disturbance driven [1]. In contrast, wetlands are very lightly connected with each other, are oblong or circular in shape and with less catastrophic disturbances in nature and less frequent than those of riparian areas [1].

The differences in physical characteristic between riparian areas and wetlands also lead to differences in some of the plant species that occupy them. Typically, riparian areas support woody plants (trees and shrubs) and emergent herbaceous plant cover (grasses and forbs) that are disturbance limited [5], such as the 
species mentioned in Chapter 3.1. In contrast, wetlands support more frequently deeper water submerged aquatic plants that are competition limited [5], such as Potamogeton spp., Nymphaea alba, Lemma spp., Trapa natans, Nympoides peltata, as well as shallow water plants such as Phragmites australis, Carex spp., Typha spp., Juncus spp. and Scirpus spp. The shallow water plants can also be present in the riparian areas.

\section{Conclusions}

Riparian areas are unique ecosystems because they have characteristics of both terrestrial and aquatic ecosystems. Their soils and vegetation differ from the adjacent terrestrial ecosystem because they are disturbance driven and have higher soil moisture content. The most important disturbances for riparian areas in semi-arid Mediterranean regions such as Greece, are floods, droughts and to a lesser degree fires. Their higher soil moisture content is the result of their close proximity to the surface freshwater bodies.

Riparian areas are established in a wide range of biomes. They are also established along setting with different hydrologic and geomorphic characteristics. This leads to a great variety of different habitat types of riparian areas, even in small countries like Greece. The riparian areas of Greece are classified based on forest vegetation in five major habitat types.

Finally, both wetlands and riparian areas are semi-aquatic ecosystems and fairly similar. Still, these ecosystems have significant differences. Riparian areas are disturbance driven with soils saturated for short long periods of times that can be in some cases nonhydric. Wetlands on the other hand are wetter (inundated with water for long periods) with soils that are always hydric. These physical characteristics lead each ecosystem to have some unique plant species, although they also have some common ones. In general, plant species that are present in riparian areas tend to be more resilient to extreme disturbances (floods and droughts), shorter water inundation periods and lower soil moisture than plants in wetlands.

\section{References}

1. R. J. Naiman, H. Décamps and M. E. McClain, Riparia: Ecology, conservation, and management of streamside communities. Elsevier Acad. Press, London, UK (2005).

2. T. T. Baker, What is a riparian area? Cooperative Extension Service. Animal Resources Dept. New Mexico State Univ. Las Cruces, NM (2002). Available at: http://aces.nmsu.edu/riparian/WHTRIPAREA.html

3. D. B. Botkin and C. E. Beveridge, Cities as environments. Urban Ecosys. 1, pp. 3-19 (1997).

4. S.V. Gregory, F. J. Swanson, W. A. McKee and K. W. Cummins, An ecosystem perspective of riparian zones, BioSci. 41, pp. 540-551 (1991).

5. National Research Council, Riparian areas: Functions and strategies for management. Natl. Acad. Sci. Washington, DC (2002).

6. M. A. Dimmitt, Biomes and Communities of the Sonoran Desert. In: S. J. Phillips and P. W. Comus, A natural history of the Sonoran Desert. Univ. of California Press. Los Angeles, CA. pp. 3-18 (2000).

7. T. I. Arabatzis, (in Greek), Shrubs and trees in Greece: Volume 1. Ecological movement of Drama. TEI Kavala. Kavala, Greece (1998).

8. T. I. Arabatzis, (in Greek), Shrubs and trees in Greece: Volume 2. Ecological movement of Drama. TEI Kavala. Kavala, Greece (2001).

9. R. H. Whittaker, Communities and ecosystems. MacMillan. New York, NY (1975).

10. P. F. Ffolliott, L. F. DeBano, M. B. Baker Jr., D. G. Neary, and K. N. Brooks, Hydrology and impacts of disturbances on hydrologic function. In: Baker Jr, M., et al Ecology and Management of Riparian Areas in the Southwestern United States: Hydrology, Ecology and Management. Lewis Publ. Boca Raton, FL. pp. 51-76 (2004).

11. Bureau of Land Management, Riparian wetland initiative for the 1990's. USDI BLM. Washington, DC (1991).

12. S. Zogaris, V. Hatzivarsanis, A.N. Ecomomou, Y. Hatznikolaou, S. Giakoumi and P. Dimopoulos, (in Greek), Riparian zones in Greece: Protecting riverine oasis of life. IIW and HCMR. Athens, Greece (2007).

13. J. V. Ward, The four dimensional nature of lotic ecosystems. J. N. Am. Benth. Soc. 8, pp.2-8,(1989).

14. C. Amoros and G. Bornette, Connectivity and biocomplexity in waterbodies of riverine floodplains. Freshwater Biology 47, pp.761-776 (2002).

15. R. R. Johnson, S. W. Carothers and J. M. Simpson, A riparian classification system. In: R. E. Warner and K. M. Hendrix (eds.), California riparian systems. Univ. of California Press. Berkeley, CA. pp. 375-382. (1984).

16. E. Marti, S. G. Fisher, J. D. Schade and N. B. Grimm, Flood frequency and stream-riparian linkages in arid lands. In: J. B. Jones and P. J. Mulholland (eds.), Streams and Ground Water. Acad. Press. New York, NY. pp. 111136 (2000).

17. R. C. Wissmar and F. J. Swanson, Landscape disturbance and lotic ecotones. In: R. J. Naiman and H. Decamps, The ecology and management of aquatic-terrestrial ecotones. UNESCO and the Parthenon Publ. Group. Paris, France. pp. 65-89 (1990).

18. E. Pieczynska, Lentic aquatic-terrestrial ecotones: Their structure, functions and importance. In: R. J. Naiman and H. Decamps (eds), The ecology and management of aquatic-terrestrial ecotones. UNESCO and the Parthenon Publ. Group. Paris, France. pp. 103-140 (1990).

19. G. M. Hornberger, J. P. Raffensperger, P. L. Wiberg and K. N. Eshleman, Elements of Physical Hydrology. The John Hopkins University Press. Baltimore, MD (1998).

20. W. S. Platts, C. Armour, G. D. Booth, M. Bryant, J. L. Bufford, P. Cuplin, S. Jensen, G. W. Lienkaemper, G.W. Minshall, S. B. Monsen, R. L. Nelson, J. R. Sedell and J. S. Tuhy, Methods for evaluating riparian habitats with applications to management. USDA FS Gen. Tech. Rep INT-221. Odgen, UT (1987).

21. G. P. Malanson, Riparian landscapes. Cambridge Univ. Press, New York, NY (1997).

22. L. Lewis, L. Clark, R. Krapf, M. Manning, J. Staats, T. Subirge, L. Townsend and B. Ypsilantis, Riparian area management: Riparian wetland soils. Tech. Ref. 1737-19. BLM, Denver, CO (2003).

23. P. Huggenberger, E. Hoehn, R. Beschta and W. Woessner, Abiotic aspects of channels and floodplains in riparian ecology. Freshwater Biology 40, pp.407-425 (1998).

24. S. Johannes and A. M. Gurnell, Spatial hydrogeomorphological influences on sediment and nutrient deposition in riparian zones: observations from the Garonne River, France. Geomorphology 49, pp.1-23 (2003).

25. J-L. E. Cartron, S. H. Stoleson, P. L. L. Stoleson and D. W. Shaw, Riparian areas. R. Jemison, R. and C. Raish, Livestock Management in the American Southwest: Ecology, Society and Economics. Elsevier Sci. Amsterdam, Netherlands. pp. 281-327 (2000).

26. R. E. Larsen, W. C. Krueger, M. R. George, M. R. Barrington, J. C. Buckhouse and D. E. Johnson, Viewpoint: Livestock influences on riparian zones and fish habitat: Literature classification. Journal of Range Management 51, pp. 661-664 (1997).

27. M. K. Fierke and J. B. Kauffman. Structural dynamics of riparian forests along a black cottonwood successional gradient. For. Ecol. Manage. 215, pp. 149-162 (2005).

28. L. M. Cowardian, V. Carter, F. C. Golet and E. T. LaRoc. Classification of wetland and deep water habitats of the United States. FWS/OBS-79/31. US FWS. Washington, DC (1979).

29. National Research Council, "Wetlands: Characteristics and boundaries". Natl. Acad. Sci. Washington, DC (1995).

30. G. W. Minshall, S. E. Jensen and W. S. Platts. The ecology of stream and riparian habitats of the Great Basin region: a community profile. Biol. Rep.85 (7.24). USDI FWS, Natl. Wetlands Res. Cen. Slidell, LA (1989). 